\title{
PENGEMBANGAN KETERAMPILAN SOSIAL ANAK USIA DINI MELALUI PERMAINAN TRADISIONAL MADURA
}

\author{
Diana Vidya Fakhriyani \\ PG PAUD FKIP Universitas Islam Madura \\ email: dianafakhriyani@gmail.com
}

Received February 2018, Accepted March 2018, Published April 2018

\begin{abstract}
Development of Social Skills of Early Chilhood of Madura Traditional Games. A person should have the social skills to be able to interact with his environment. Social skills should be developed at an early age, because at this early age individuals have learned to socialize with other individuals. Therefore, social skills can be developed from an early age, so that children can play a role in socializing with his environment. Development of early child social skills can be done with many things, one of Madurese traditional game. The traditional game of Madura is a game in Madura, which in fact is currently largely abandoned. There are various kinds of Madurese traditional games, where in this article there are games Kocheng-tekos and bhisek as one of the development alternatives that can be applied in order to develop social skills for early childhood.
\end{abstract}

\section{Keywords: Social Skill, Early Childhood, Traditional Game of Madura}

Abstrak: Pengembangan Keterampilan Sosial Anak Usia Dini Melalui Permainan Tradisional Madura. Seseorang hendaknya memiliki keterampilan sosial agar mampu dalam berinteraksi dengan lingkungannya. Keterampilan sosial seharusnya dapat dikembangkan saat usia dini, karena pada usia dini ini individu telah belajar bersosialisasi dengan individu lainnya. Maka dari itu, keterampilan sosial dapat dikembangkan sedari dini, sehingga anak dapat memainkan perannya dalam bersosialisasi dengan lingkungannya. Pengembangan keterampilan sosial anak usia dini dapat dilakuakan dengan berbagai hal, salah satunya melalui permainan tradisional Madura. Permainan tradisional Madura merupakan permainan yang ada di Madura, yang faktanya saat ini banyak ditinggalkan. Terdapat berbagai macam permainan tradisional Madura, dimana dalam artikel ini ada permainan Kocheng-tekos dan bhisek sebagai salah satu alternatif pengembangan yang dapat diterapkan dalam rangka mengembangkan keterampilan sosial bagi anak usia dini.

\section{Kata Kunci: Keterampilan Sosial, Anak Usia Dini, Permainan Tradisional Madura}

Pendidikan usia dini tak lain merupakan pendidikan yang diberikan pada individu sejak dini, yang mana pendidikan tersebut tidak hanya mencakup aspek kognitif saja, melainkan juga aspek sosial dan emosional. Sehingga individu yang diberikan pendidikan menyeluruh sejak dini, akan menjadi individu yang sukses. Karena penelitian sebelumnya menunjukkan bahwa kesuksesan individu dipengaruhi oleh aspek kognitif hanya sebanyak $20 \%$ dan $80 \%$ sisanya dipengaruhi oleh faktor lain, termasuk di dalamnya aspek sosio-emosional. Aspek sosio-emosinal berkaitan dengan keterampilan sosial, yakni kemampuan individu dalam bersosialisasi dengan lingkungan sekitarnya. Setiap individu hendaknya memiliki keterampilan dalam bersosialisasi dengan masyarakat lainnya, agar dapat diterima di lingkungan dimana ia tinggal. Karena faktanya, tidak sedikit individu yang memiliki keterampilan sosial yang rendah sehingga individu tersebut tidak dapat beradaptasi dengan lingkungannya.

Keterampilan sosial merupakan perilaku yang dapat diterima secara sosial (Takahashi, Okada, Hoshino, \& Anme, 2015). Keterampilan dapat dipelajari dan dikembangkan agar individu dapat beriteraksi secara efektif. Keterampilan sosial hendaknya dikembangkan sejak dini, agar sedari dini individu dapat bersosialisasi dengan lingkungan sekitarnya yaitu dengan orangtua, guru, teman sebaya, dan masyarakat di sekitarnya. Sehingga kelak ketika dewasa, individu tersebut memiliki keterampilan sosial yang tinggi yang mudah berinteraksi dengan lingkungannya.

Pengembangan keterampilan sosial merupakan salah satu pencapaian penting bagi anak usia dini untuk menciptakan hubungan dengan orang lain.Sebaliknya, ketika pada masa anak-anak gagal membangun keterampilan sosial dengan baik, dengan kata 
40 Jurnal PG-PAUD Trunojoyo : Jurnal Pendidikan dan Pembelajaran Anak Usia Dini, Volume 5, Nomor 1, April 2018, hal $39-44$

lain keterampilan mereka tidak berfungsi secara efektif pada tahap perkembangan awal, maka mereka akan menunjukkan perilaku bermasalah dan mengalami maladaptasi sosial, ketidakmampuan sekolah, dan kinerja akademis yang buruk (Arnold DH, 2012).

Pengembangan keterampilan sosial pada anak usia dini terintegrasi dalam pembelajarannya, sehingga dalam mengembangkan keterampilan sosial tersebut dapat dilakukan dengan berbagai cara dan strategi termasuk diantaranya dengan cara bermain. Dalam bermain terdapat permainanpermainan yang dapat dilakukan dalam rangka menggembangkan keterampilan anak usia dini. Termasuk permainan tradisional Madura yang saat ini mulai banyak ditinggalkan, padahal dalam permainan tradisional terdapat manfaat yang besar yakni dapat meningkatkan keterampilan sosial anak. Maka dari itu, keterampilan sosial anak usia dini dapat dikembangkan melalui permainan tradisional Madura, yakni Kocheng-tekos dan bhisek.

\section{METODE}

Penelitian pengembangan (research \& development) adalah suatu jenis penelitian yang menjembatani antara peneliti yang menghasilkan teori-teori dan pengguna produk. Menurut Sugiyono (dalam Pramono, 2013:102) metode penelitian dan pengembangan adalah metode penelitian yang digunakan untuk menghasilkan produk tertentu, dan menguji keefektifan produk tersebut. Sedangkan menurut Ardana (2002:1) penelitian dan pengembangan yang berarti penerapan informasi atau pengetahuan untuk menciptakan produk atau proses. Dalam penelitian ini mengembangkan permainan tradisional Madura untuk meningkatkan keterampilan sosial anak.

Penelitian ini dilakukan dengan mengikuti langkah-langkah penelitian dan pengembangan sebagai berikut: (1) penelitian dan pengumpulan data, (2) perencanaan, (3) pengembangan draft produk, (4) uji coba, (5) merevisi hasil uji coba, (6) uji coba lapangan, dan (7) penyempurnaan produk. Subjek penelitian yang terlibat dalam penelitian dan pengembangan ini adalah guru PAUD dan anak-anak perwakilan dari PAUD di Kabupaten Pamekasan. Jenis penelitian ini merupakan data kualitatif.
Data dikumpulkan melalui wawancara dan pengamatan terhadap keterampilan sosial anak. Data kemudian dianalisis dengan analisis kualitatif.

\section{HASIL DAN PEMBAHASAN Keterampilan Sosial Anak Usia Dini}

Keterampilan sosial adalah perilaku individu yang mendorong interaksi positif dengan orang lain dan lingkungan. Beberapa keterampilan ini meliputi menunjukkan empati, partisipasi dalam aktivitas kelompok, kemurahan hati, menolong, berkomunikasi dengan orang lain, negosiasi, dan pemecahan masalah (A. Lynch, 2010).

Menurut Sjamsuddin dan Maryani (2008: 6) keterampilan social adalah suatu kemampuan secara cakap yang tampak dalam tindakan, mampu mencari, memilah dan mengelola informasi, mampu mempelajari halhal baru yang dapat memecahkan masalah sehari-hari, mampu memiliki keterampilan berkomunikasi baik lisan maupun tulisan, memahami, menghargai dan mampu bekerjasama dengan orang lain yang majemuk, mampu mentransformasikan kemampuan akademik dan beradaptasi dengan perkembangan masyarakat.

Mu'tadim Zainun (2006) berpendapat bahwa keterampilan sosial adalah kemampuan atau kecakapan yang dimiliki seseorang untuk menyesuaikan diri dan berinteraksi dengan lingkungannya yang meliputi kemampuan berkomunikasi, menjalin hubungan dengan orang lain, menghargai diri sendiri dan orang lain, memberi dan menerima kritik yang diberikan orang lain.

Keterampilan sosial merupakan kemampuan individu dalam bersosialisasi di lingkungan sekitarnya. Hal tersebut berkaitan dengan bagaimana kemampuan individu dalam berinteraksi dengan individu lainnya. Keterampilan sosial membutuhkan pengetahuan dan latihan untuk dapat melakukan kegiatan bermasyarakat dengan baik, agar selanjutnya memiliki keterampilan sosial yang tinggi. Keterampilan sosial erat kaitannya dengan bagaimana individu berprilaku atau perilaku sosial. Perilaku sosial berkembang pesat pada masa usia dini yakni masa kanak-kanak atau usia pra sekolah. Hal tersebut dikarenakan bertambahnya pengalaman bersosialisasi anak. Maka dari itu keterampilan sosial anak perlu dikembangkan 
Jurnal PG-PAUD Trunojoyo : Jurnal Pendidikan dan Pembelajaran Anak Usia Dini, Volume 5, Nomor 1,

agar anak dapat memainkan perannya dalam masyarakat sekitarnya.

Keterampilan sosial terdapat dalam kompetensi sosial dan tanggung jawab sosial, dimana keduanya meliputi pengetahuan, keterampilan dan sikap sosial. Sikap sosial merupakan kemampuan anak dalam merasakan apa yang dirasakan oleh orang lain, termasuk prosocial behavior (perilaku prososial) yang menerminkan anak memiliki keterampilan sosial yang tinggi.

Menurut Junice J. Beaty, keterampilan social disebut juga pro social behavior yang mencakup perilaku seperti: a) empati yang di dalamnya anak-anak mengekspresikan rasa haru dengan memberikan perhatian kepada seseorang yang sedang tertekan karena suatu masalah dan mengungkapkan perasaan orang lain yang sedang mengalami konflik sebagai bentuk bahwa anak menyadari perasaan orang lain, b) kemurahan hati atau dermawan di dalamnya anak-anak berbagi dan memberikan suatu barang miliknya pada seseorang, c) kesadaran yang didalamnya anak-anak mengambil giliran atau bergantian dan dapat memenuhi perintah secara sukarela tanpa menimbulkan pertengkaran, d) memberi bantuan yang didalamnya anak-anak membantu orang lain untuk melengkapi suatu tugas dan membantu orang lain yang membutuhkannya.

Keterampilan sosial merupakan kemampuan untuk mengadakan komunikasi satu individu dengan individu yang lain seperti; perilaku yang berorientasi pada tugas yaitu kemmapuan untuk mengambil tanggung jawab untuk bekerja dan bekerjasama dalam kelompok, menjadi kreatif dalam bekerja, dan berusaha untuk mendapat kualitas dalam bekerja. Pada hakikatnya keterampilan sosial dapat dikembangkan dan dimanifestasikan dalam interaksional.

Anak yang menarik diri dalam kegiatan kelompok dapat diindikasikan bahwa anak tersebut memiliki keterampilan sosial yang rendah. Keterampilan sosial merupakan bagian dari tugas perkembangan yang harus dituntaskan dan terbentuk dari proses pembiasaan yang dilakukan ketika masa kanak-kanak. Dalam rangka menuntaskan tugas perkembangan dan agar selanjutnya anak memiliki keterampilan sosial yang tinggi, perlu dilakukan latihan dan pengembangan dalam meningkatkan keterampilan sosial anak usia dini.

\section{Permainan Tradidional Madura}

Anak usia dini tidak terlepas dari kegiatan bermain, karena masa kanak-kanak merupakan masa bermain. Kegiatan bermain memiliki berbagai manfaat yang memungkinkan anak berkembang secara optimal. Bermain merupakan cara belajar anak usia dini yang tidak sama dengan cara belajar orang dewasa. Bermain dapat pula mempengaruhi semua perkembangan, termasuk perkembangan sosial yang meliputi keterempilan sosial dengan memberikan kesempatan pada kepada anak untuk mengeksplor dirinya sendiri, orang lain dan lingkungan sekitarnya.

Bermain merupakan aktifitas jasmani yang dilakukan dengan sukarela dan bersungguh-sungguh untuk memperoleh rasa senang dari aktivitas yang dilakukan tersebut. Bermain merupakan suatu perbuatan atau kegiatan sukarela, yang dilakukan menurut aturan yang telah diterima secara sukarela, tapi mengikat sepenuhnya, dengan tujuan dalam dirinya, disertai oleh perasaan tegang dan gembira, dan kesadaran "lain daripada kehidupan sehari-hari”, (Johan Huizinga).

Bermain adalah bermakna simbolis, aktif, menyenangkan, sukarela, dan aturan yang tidak baku (Fromberg). Bermain merupakan suatu aktifitas yang harus dilakukan dengan sungguh-sungguh dan sukarela atas dasar rasa senang, tetapi bermain bukan merupakan kesungguhan (kegiatan untuk memperoleh uang/penghidupan), (Sukintaka, 1982: 1)

Dalam bermain terdapat berbagai macam permainan, diantaranya adalah permainan tradisional. Beragam permainan tradisional mempunyai banyak manfaat yaitu dapat mengarahkan anak menjadi kuat baik secara fisik dan mental, maupun sosial dan emosional, tidak mudah menyerah dalam mengeksplor dan bereksperimen, dapat menumbuhkan jiwa kepemimpinan dan jiwa sosial, serta menumbuhkan jiwa kooperatif atau kerjasama dalam tim. Semua kegiatan dalam permainan tradisional yang dimainkan oleh anak-anak mempunyai makna tersendiri yang dapat memaksimalkan seluruh potensi anak.

Hal senada diungkapkan oleh Archoni yang menjelaskan, bahwa bermain memberi banyak manfaat bagi anak seperti mampu mengembangkan kecerdasan 
42 Jurnal PG-PAUD Trunojoyo : Jurnal Pendidikan dan Pembelajaran Anak Usia Dini, Volume 5, Nomor 1, April 2018, hal $39-44$

intelektual anak, mengembangkan kemampuan motorik halus dan kasar anak, meningkatkan kemampuan berkonsentrasi dalam meemcahkan masalah dan juga untuk kesehatan anak (Cahyani dkk, 2014). Argumen Danandjadja yang dikutip Archoni menyatakan bahwa permainan tradisional sebagai salah satu bentuk permainan anakanak yang beredar secara lisan dan kolektif, berbentuk tradisional dan diwaris turun temurun, serta memiliki banyak variasi (Cahyani, Kristianatar, \& Manuaba, 2014). Selanjutnya, Archoni menjelaskan beberapa bentuk-bentuk permainan tradisional di Indonesia, antara lain adalah a). Engklek/Dengkleng, b). Curik-curik (Ular tangga), c). Congklak, d). meong-meong, e). Gobak Sodor/Megala-gala, f). Balap karung, g). Petak umpet, h). Lompat tali, i). Kelereng/Guli, j). Engrang/Tajog Kau. Ada juga permainan tradisional lainnya seperti alat musik dengan pelepah pisang, marakas, telepon bambu, perahu kertas, layang-layang dan gasing (Cahyani, Kristianatar, \& Manuaba, 2014).

Permainan tradisional Madura juga sama dengan permainan tradisional yang telah disebutkan sebelumnya, perbedaannya hanya terletak pada bahasa daerah dan pengucapannya. Dari banyaknya permainan tradisional Madura, penulis lebih menekankan pada permainan kocheng-tekos dan bhisek. Kedua permainan tradisional tersebut dapat meningkatkan keterampilan sosial anak usia dini.

\section{Permainan Tradisional Madura "Kocheng- tekos"}

Permainan kocheng-tekos merupakan salah satu permainan tradisional yang menggambarkan cerita kucing yang tidak berhenti mengejar tikus. Dalam permainan ini anak-anak ada yang akan berperan menjadi si kucing, si tikus, dan pagar. Anak yang menjadi si kucing harus menangkap anak yang menjadi si tikus. Untuk bersembunyi, si tikus dapat bersembunyi di lingkaran pagar yang dibuat oleh teman-temannya yang lain supaya tidak tertangkap oleh si kucing.

Permainan ini dapat mengembangkan fisik-motorik, sosial, dan emosional anak. Dalam permainan ini membutuhkan kerjasama tim, sehingga komunikasi antara anak yang berperan menjadi "Tikus" dan anak yang berperan menjadi "pagar" sangat dibutuhkan. Dengan adanya komunikasi, pada permainan ini dapat meningkatkan keterampilan bersosialisasi anak.

\section{Permainan Tradisional Madura "Bhisek"}

Permainan tradisional Madura bhisek ini, juga terdapat di daerah lainnya di Indonesia. Perbedaannya hanya terletak pada nama permainan tersebut karena setiap daerah di Indonesia memiliki nama masing-masing untuk permainan tradisional ini. Misalnya di Jawa permaianan ini disebut dengan Engklek.

Engklek adalah permainan yang sudah ada secara turun temurun, permainan ini dilakukan dengan cara berjalan atau melompat dengan menggunakan satu kaki. Engklek merupakan permainan tradisional yang dilakukan di halaman dengan menggambar kotak-kotak kemudian melompat dan melompat lagi ke kota-kotak berikutnya (Margareta, 2015).

Permainan tradisional ini merupakan permainan melompat pada bidang-bidang datar yang digambar di atas tanah atau plester depan rumah/jalan, dengan membuat kotak-kotak kemudian melompat dengan satu kaki dari kotak satu ke kotak berikutnya (Apriani, 2016).

Permainan bhisek di Madura sudah ada sejak lama dan sudah turun temurun namun dewasa ini, bhisek sudah jarang dijumpai dan mulai ditinggalkan. Padahal bhisek memiliki banyak manfaat untuk perkembangan anak yakni perkembangan fisik-motorik anak. Bhisek dapat meningkatkan perkembangan motorik kasar anak. Selain itu bhisek juga dapat meningkatkan kemampuan sosial anak, karena dengan bermain permainan bhisek ini anak dapat berkomunikasi dan bersosialisasi dengan teman sepermainannya. Sehingga melalui permainan ini secara tidak langsung anak mengasah sekaligus latihan dalam mengembangkan keterampilan sosial.

\section{Keterkaitan Keterampilan Sosial Anak Usia Dini Dengan Permainan Tradisional Madura}

Keterampilan sosial anak usia dini merupakan kemampuan anak dalam bersosialisasi dengan lingkungannya. Kemampuan bersosialisasi ini penting dimiliki oleh setiap individu dan peting untuk dikembangkan sejak dini, karena keterampilan 
Jurnal PG-PAUD Trunojoyo : Jurnal Pendidikan dan Pembelajaran Anak Usia Dini, Volume 5, Nomor 1,

sosial bagi anak usia dini merupakan salah satu pencapaian yang harus dituntaskan juga sebagai bekal bermasyarakat ketika dewasa kelak. Pengembangan keterampilan sosial dapat dilakukan dengan berbagai cara, salah satu diantaranya melalui permainan tradisional Madura. Permainan tradisional Madura merupakan permainan tradisional di Madura yang saat ini sudah mulai ditinggalkan, padahal permainan tradisional memiliki berbagai macam manfaat yakni untuk dapat mengembangkan fisik-motorik, kemampuan intelektual, pengembangan emosional, dan pengembangan bersosialisasi. Dari sekian banyak permainanan tradisional Madura, salah satu permainan yang dapat mengembangkan keterampilan sosial anak usia dini yakni kocheng-tekos \& Bhisek.

\section{PENUTUP}

\section{Kesipulan}

Keterampilan sosial merupakan perilaku individu yang mampu berinteraksi secara positif dengan masyarakat sekitarnya. Ciri-ciri anak usia dini yang memiliki keterampilan sosial diantaranya pertama adalah memiliki sikap empati, yakni anak dapat merasakan hal yang dirasakan orang lain; Kedua dapat berpartisipasi dalam aktivitas kelompok teman sebayanya; memiliki sikap prososial, yakni suka menolong.

Keterampilan sosial berkaitan erat kaitannya dengan bagaimana individu berprilaku atau perilaku sosial. Perilaku sosial berkembang pesat pada masa usia dini yakni masa kanak-kanak atau usia pra sekolah. Hal tersebut dikarenakan bertambahnya pengalaman bersosialisasi anak. Maka dari itu keterampilan sosial anak perlu dikembangkan agar anak dapat memainkan perannya dalam masyarakat sekitarnya. Maka dari itu, pengembangan keterampilan sosial pada anak usia dini sangat penting untuk dimaksimalkan.

Pengembangan keterampilan sosial anak usia dini dapat dilakukan dengan berbagai macam cara, termasuk dalam pembelajarannya. Salah satu diantaranya melalui permainan tradisional Madura. Terdapat berbagai macam permainan tradisional, diantaranya adalah permainan kocheng-tekos dan bhisek. Kedua permainan ini dapat mengembangkan seluruh potensi anak usia dini, baik dari segi fisikmotorik, intelektual, dan sosial emosional, yang termasuk keterampilan sosial anak.

\section{Saran}

Artikel ini disusun bedasarkan fenomena tentang keterampilan anak usia dini yang sangat penting untuk dikembangkan diantaranya melalui permainan tradisional Madura. Pada kenyataannya seiiring perkembangan zaman, permainan tradisional Madura mulai banyak ditinggalkan. Artikel ini masih bersifat teoritik, maka dari itu sangat dibutuhkan kajian empiris sebagai tindak lanjut dalam artikel ini. Tindak lanjut artikel ini yang berupa kajian empiris atau berupa penelitian, diharapkan dapat mengukur sejauh mana keberhasilan permainan tradisional Madura dapat mengembangkan keterampilan sosial anak usia dini.

\section{DAFTAR PUSTAKA}

Apriani, D. (2016). Penerapan Permainan Tradisional Engklek Untuk Meningkatkan Kemampuan Motorik Kasar Anak Kelopok B RA AlHidayah 2 Tarik Sidoarjo. Jurnal UNESA, 04.

Ardana, W. (2002). Konsep Penelitian Pengembangan dalam Bidang Pendidikan dan Pembelajaran. Malang: Universitas Negeri Malang

Arnold DH, K. J.-L. (2012). The association between preschool children's social functioning and their emergent academic skills. Early Child Res $Q$, 27, 376-386.

Cahyani, N. L., Kristianatar, M. R., \& Manuaba, S. (2014). Model Pembelajaran Quantum Melalui Permainan Tradisional Untuk Meningkatkan Kognitif Anak Kelompok B TK Kumara Jaya Denpasar. e-Jounal PG-PAUD Universitas Pendidikan Ganesha Jurusan Pendidikan Anak Usia Dini.

Ismail, R. (2016). Increasing Student's Social Skill Through Playing Methode. Jurnal Pendidikan Usia Dini, 315326.

Jamson, K. R., Forston, L. D., \& Chapman, T. L. (2012). Encouraging Social Skill Development Through Play In Early Childhood Special Education Classroom. SAGE Journal. 
44 Jurnal PG-PAUD Trunojoyo : Jurnal Pendidikan dan Pembelajaran Anak Usia Dini, Volume 5, Nomor 1, April 2018, hal 39 - 44

Lestariningrum, A. (2017). Penerapan Permainan Tradisional dalam Pembelajaran Anak Usia Dini. Seminar Nasional Penguatan Kemitraan, Akademisi, Satuan Pendidikan PAUD, Keluarga dan Masyarakat Menuju Profesionalitas (pp. 01-08). Surabaya: Jurusan PGPAUD Fakultas Ilmu Pendidikan Universitas Negeri Surabaya.

Lynch, S. A. (2010). Social Skills: Laying The Foundation For Succes. DIMENSIONS OF EARLY CHILDHOOD, 03-11.

Margareta, A. G. (2015). Pengaruh Permainan Engklek Terhadap Keamampuan Loncat Anak Usia 4-5 Tahun di TK PKK Semanding dan TK Aisyiyah Pabelan. UMS.

Pramono. (2013). Pengembangan Permainan Sirkuit dari Limbah untuk Pembelajaran Fisik Motorik Anak Usia Dini Usia 3-4 Tahun. Jurnal PAUD. Vol. 1, No. 2, hlm. 100-107.

Takahashi, Y., Okada, K., Hoshino, T., \& Anme, T. (2015). Developmental Trajectories of Social Skills during Early Childhood and Links to Parenting Practices in a Japanese Sample. Journal Plos. 